\title{
Contando o Atraso Educacional: Despesas e Matrículas na Educação Primária de São Paulo (1880-1920)
}

\author{
Renato Perim Colistete \\ Professor livre-docente do Departamento de Economia. Faculdade de Economia, Administração, \\ Contabilidade e Atuária (FEA-USP). São Paulo, SP. Brasil. \\ E-mail: rcolistete@usp.br, https:/ /orcid.org/0000-0002-1061-3914
}

\section{INTRODUÇÃO}

\begin{abstract}
o final do século XIX, o atraso educacional do Brasil era uma realiddade há muito reconhecida por publicistas, políticos e governantes. Por volta de 1900, a taxa de matrícula nas escolas primárias do país chegava a apenas 29 crianças por 1.000 habitantes, enquanto Estados Unidos (203), Canadá (185) e Alemanha (158) alcançavam índices mais de cinco vezes maiores. Mesmo na América Latina o Brasil situava-se entre os países com as menores taxas de matrícula, muito atrás, por exemplo, de Argentina (98), Uruguai (79), Peru (72) e Chile (68) (Brasil, 1916: CCXX-CCXXI; Brasil, s.d.:1398). Os números do Brasil eram o reflexo das políticas educacionais implementadas por províncias e, depois, estados. Desde a lei geral de 15 de outubro de 1827, corroborada pelo Ato Adicional de 12 de agosto de 1834, a instrução primária permaneceu sob jurisdição das províncias, atribuição igualmente conferida aos estados pela Constituição republicana de $1891^{1}$.
\end{abstract}

São Paulo, vivendo então um excepcional crescimento econômico estimulado pelas exportações de café e atividades relacionadas, encontrava-se em uma situação peculiar. Embora em meados do século XIX a Província se situasse abaixo da média nacional em matrículas, já na década de 1880 São Paulo havia superado seu relativo atraso frente a outras unidades administrativas do Império, alcançando posição de liderança no país em 1920 ao lado de Santa Catarina e Distrito Federal. Não obstante esse expressivo desempenho, São Paulo não se distanciou muito dos países mais atrasados educacionalmente da Europa, como Portugal, e suas taxas de matrícula não passaram de metade do índice da Argentina, a nação líder da educação primária na América

DADOS, Rio de Janeiro, vol.62(2):e20170105, 2019. 
Latina. Por sua vez, o Brasil como um todo continuou exibindo nas primeiras décadas do século XX um dos piores indicadores educacionais no mundo, não apenas inferiores aos dos países mais atrasados na instrução primária da Europa, como também equivalentes aos das nações com os menores níveis educacionais na própria América Latina (como Bolívia e Guatemala). São esses resultados frente a outros países, como notado por Stanley Engerman, Elisa Mariscal e Kenneth Sokoloff, que tornam o Brasil e suas unidades administrativas um caso especial para o estudo das trajetórias divergentes de instituições da educação primária, instituições políticas e desempenho econômico nas Américas. Se os níveis educacionais das nações tiveram algum efeito sobre seu crescimento econômico de longo prazo, uma importante questão a ser investigada diz respeito às condições da oferta de educação primária tanto em países específicos e suas regiões quanto em termos internacionais (Engerman, Mariscal e Sokoloff, 2009:3-95, 105).

Vistos sob o ângulo das comparações internacionais, os resultados negativos da instrução primária do Brasil contrastam com as avaliações mais frequentes sobre o sistema educacional do país a partir da proclamação da República e nas primeiras décadas do século XX. Com a liderança de São Paulo, as políticas implementadas pelos republicanos promoveram mudanças abrangentes na organização e nos métodos pedagógicos da instrução pública, bem como levaram à ampliação das matrículas do ensino primário. Essas mudanças são geralmente entendidas como parte de um projeto maior de transformação das instituições políticas, ideológicas e econômicas que consolidaram o poder de uma nova elite cafeeira que emergiu como grupo social hegemônico da Primeira República² ${ }^{2}$

Não obstante, e apesar dos resultados positivos obtidos durante as primeiras décadas do século XX, a ênfase excessiva - e muitas vezes apologética - nas políticas educacionais após a instalação da República obscurece dois fatos centrais do período: primeiro, que o acesso à educação primária para a maioria das crianças em idade escolar continuou altamente restrito e desigual, com o Brasil mantendo-se entre as nações com os piores indicadores educacionais do mundo, tal como acontecia em meados do século XIX; segundo, que o aumento das despesas e matrículas na instrução primária em São Paulo situou-se significativamente abaixo da capacidade de investimento público permitida pelo aumento excepcional das receitas fiscais durante o boom da economia cafeeira no período. Como resultado, 
quando são consideradas as rendas públicas disponíveis, o esforço fiscal dedicado à instrução primária nas primeiras décadas da República em São Paulo foi substancialmente menor do que o realizado durante os últimos anos do Império.

Trataremos dessas questões em detalhes a seguir. A primeira seção apresenta dados e estimativas de despesas com instrução primária em São Paulo entre 1880 e 1920, compreendendo portanto a última década do Império e os anos de consolidação do regime republicano. A segunda seção reconstitui os dados de matrícula no ensino elementar, comparando-os no final com os indicadores de outros estados e países. A última seção resume as conclusões principais.

\section{AS DESPESAS COM INSTRUÇÃO PÚBLICA}

Enquanto em 1855 as despesas per capita com instrução pública na província de São Paulo alcançaram apenas $83 \%$ da média brasileira, esses gastos superaram em $21 \%$ a média nacional em 1886. Ainda assim, nesse último ano outras províncias - tais como Pará, Espírito Santo, Pernambuco e Rio de Janeiro - apresentavam índices substancialmente superiores ao registrado por São Paulo. Nas três décadas seguintes, porém, o crescimento das despesas no ensino paulista continuaria acelerado e, em 1920, São Paulo alcançaria a liderança dos gastos com instrução pública no Brasil.

A Figura 1 sintetiza esses indicadores para um conjunto de províncias e estados selecionados. Em 1907, o Estado de São Paulo deu um salto em relação à média nacional de gastos com a instrução pública (isto é, abrangendo todos os níveis de ensino, além do primário). De fato, a diferença de São Paulo, cuja despesa média per capita era $21 \%$ maior do que a média brasileira em 1886, subiu para 144\% em 1907. Duas das províncias que em 1886 possuíam níveis de dispêndio real maiores do que São Paulo - Rio de Janeiro (178) e Rio Grande do Sul (137) - foram ultrapassadas na primeira década do século XX. O Estado do Rio de Janeiro chegou a ficar abaixo (89) da média nacional em 1907, enquanto o Rio Grande do Sul (145) aumentou a distância em relação ao conjunto dos estados. Ainda nesta época, dois estados da região Norte, vivendo seu próprio boom com as exportações de borracha, possuíam despesas por habitante mais elevadas do que São Paulo: Pará, com índice de 395, e Amazonas, com $313^{3}$. 
Na década de 1910, São Paulo prosseguiu expandindo suas despesas com instrução pública em ritmo mais acelerado do que o de outros estados, alcançando um gasto per capita três vezes maior do que a média nacional (índice de 301) em 1920. O Rio Grande do Sul teve queda relativa no indicador (117), enquanto Rio de Janeiro (91), Minas Gerais (69) e Bahia (24) praticamente mantiveram suas despesas por habitante em relação ao início do século (Figura 1). Amazonas (146) e Pará (108), por sua vez, sofreram declínio relativo em 1920 ainda maior do que o Rio Grande do Sul, provavelmente já por reflexo do colapso das exportações de borracha sobre as suas finanças públicas. Portanto, ao final de três décadas após a derrubada da Monarquia, o Estado de São Paulo concluiu um ciclo que o levou a uma posição de liderança nos investimentos em ensino público no Brasil ${ }^{4}$.

Figura 1

Despesa per capita com instrução pública, Estados selecionados, 1886-1920

$($ Brasil $=100)$

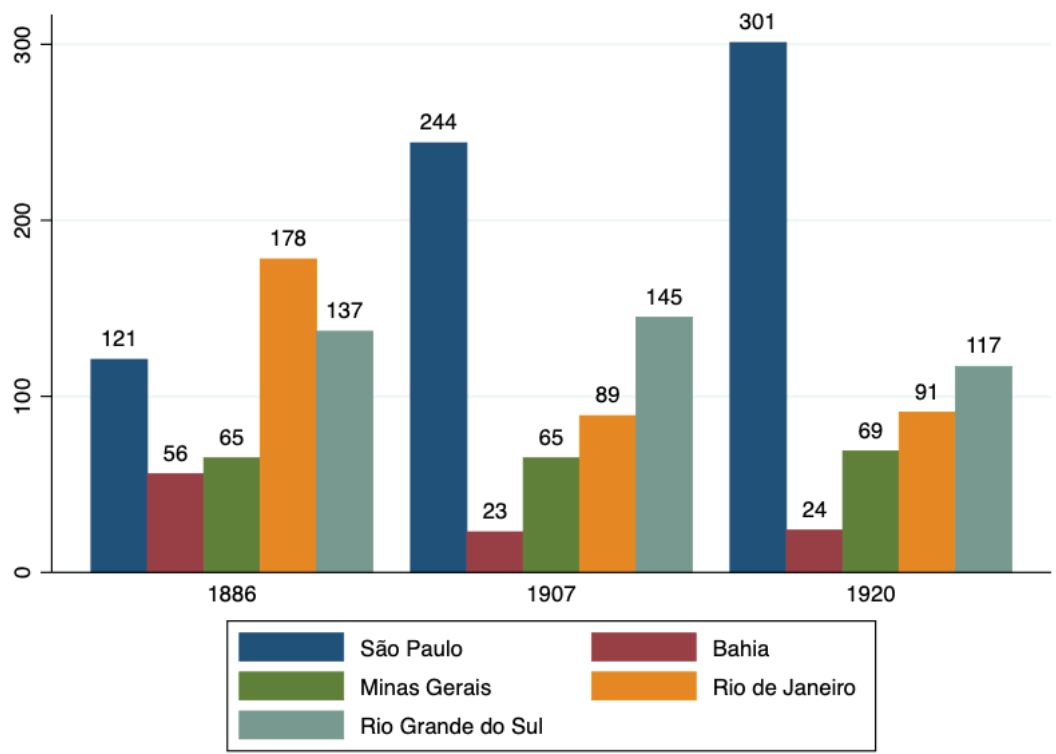

Fonte: Colistete (2016).

Um quadro mais detalhado da evolução das despesas de São Paulo com a instrução pública e, em especial, as escolas primárias é apresentado na Tabela 1, que traz a média quinquenal dos gastos com instrução pública e primária em relação às despesas do governo de São Paulo entre os anos de 1881 e 1920. Os gastos com instrução primária 
até 1888 foram estimados a partir das leis orçamentárias aprovadas pela Assembleia Legislativa, com exceção dos anos de 1883 e 1887, quando foi possível obter as despesas efetivas nos balanços das contas públicas estaduais ${ }^{5}$. A partir de 1889, os dados correspondem aos gastos com instrução primária efetivamente realizados pelo governo estadual.

Tabela 1

Despesas com instrução, governo de São Paulo (1881-1920) (em porcentagem da despesa pública total, médias quinquenais)

\begin{tabular}{ccc}
\hline Anos & Instrução pública & Instrução primária \\
\hline $1881-1885$ & 14,9 & 14,1 \\
$1886-1890$ & 17,3 & 16,1 \\
$1891-1895$ & 8,2 & 6,9 \\
$1896-1900$ & 12,3 & 8,9 \\
$1901-1905$ & 14,4 & 10,6 \\
$1906-1910$ & 13,6 & 10,4 \\
$1911-1915$ & 14,9 & 11,3 \\
$1916-1920$ & 18,4 & 14,0 \\
\hline
\end{tabular}

Fontes: São Paulo, Orçamentos e balanços (até 1888); São Paulo (1912:216; 1940:9).

Nota: os anos indicados até 1890 referem-se aos anos fiscais; por exemplo, o ano de 1885 corresponde ao ano fiscal de 1884-1885. A partir de 1890, o ano fiscal é igual ao próprio ano-calendário.

O primeiro fato a ser observado é que as despesas com instrução pública e primária continuaram aumentando em relação ao total dos gastos governamentais na última década do Império, tal como vinha ocorrendo nos anos anteriores. Assim, o dispêndio com a instrução pública atingiu 17,3\%, com a instrução primária chegando a 16,1\% dos gastos totais do governo de São Paulo em 1886-1890. Já nos anos imediatamente posteriores à proclamação da República, houve acentuada queda relativa das despesas públicas com ensino em São Paulo - 8,2\% com instrução pública e 6,9\% com instrução primária no quinquênio 1891-1895 (Tabela 1). Em parte, essa redução deveu-se ao declínio absoluto das despesas em termos reais ocorrido no ano de 1892, de 35\% no caso da verba para instrução pública e 38\% para instrução primária. Mas a causa principal da queda relativa foi que o crescimento real dos gastos com educação ocorrido nos outros anos do quinquênio revelou-se muito inferior ao ocorrido nas despesas estaduais, impulsionadas pelo aumento das receitas durante o iní- 
cio da República. Enquanto a despesa global do Estado de São Paulo praticamente quintuplicou entre 1890 e 1895, os gastos reais com a instrução pública pouco mais que dobraram e as despesas com instrução primária cresceram ainda menos $(81 \%)^{6}$.

Nos anos seguintes, a instrução pública recuperou sua participação nas despesas do Estado de São Paulo e chegou a ultrapassar $(18,4 \%)$, em 1916-1920, o percentual registrado no último quinquênio do Império $(17,3 \%)$. Por outro lado, o aumento da participação relativa da instrução primária nas despesas totais foi mais lento e limitado. Em 1896-1900, os gastos com instrução primária situavam-se em torno de 9\% das despesas ordinárias do Estado de São Paulo contra uma participação de 16\% em 1886-1890. Em 1916-1920, os percentuais das escolas primárias subiram para uma média de $14 \%$, o que ficava ainda assim abaixo do alcançado no final do Império (Tabela 1). Essa evolução desigual indica que o aumento das despesas com instrução pública nas primeiras décadas da República favoreceu os outros níveis do ensino em detrimento da instrução primária.

Como o ensino básico tinha abrangência mais ampla e absorvia a maior parte dos recursos da instrução pública, a despesa per capita (total da população) com instrução primária superou por ampla margem a realizada com a instrução secundária e, a partir de 1893, a instrução superior no Estado de São Paulo. Em 1894, por exemplo, a despesa com escolas primárias foi de 1.248 réis por habitante, enquanto os gastos com ensino secundário atingiram 154 réis, e com ensino superior, 77 réis por habitante (em valores de 1913) (Colistete, 2016: Apêndice B, Tabela B-11). Mas, como já observado, as despesas com instrução pública do governo de São Paulo evoluíram de maneira distinta de acordo com os níveis de ensino.

A Figura 2 compara o crescimento das despesas reais do governo de São Paulo com instrução primária, secundária e superior entre 1889 e 1920. Os índices do primeiro gráfico da Figura 2 têm como base o ano de 1894, a fim de capturar o primeiro exercício fiscal em que os gastos com ensino superior tornaram-se substanciais após o início das despesas com universidades em 1893. A Figura mostra que a despesa real per capita com instrução primária mais que triplicou entre o último ano fiscal do Império, 1889 (índice igual a 82), e 1914 (285), declinando em seguida até 1919 (177) e apresentando leve recuperação em 1920 (183). Não há dúvida, portanto, de que 
o crescimento das despesas com instrução primária durante o período republicano foi expressivo, mesmo com a queda relativa dos gastos reais per capita a partir de 1915.

A primeira parte da Figura 2 também mostra, no entanto, que o crescimento mais significativo das despesas com instrução pública ocorreu no ensino secundário. Saindo de um nível per capita reduzido em 1889 (índice igual a 35, 1894=100), os gastos com escolas secundárias multiplicaram-se mais de 16 vezes em termos reais até meados da década de $1910(1914=582)$, declinando drasticamente nos anos seguintes (1920 = 269). Os estabelecimentos de nível secundário incluíam ginásios, escolas complementares e escolas normais, que se espalharam pela capital e pelo interior do estado. Outro nível que passou por uma rápida expansão foi o ensino superior, com a criação da Escola Politécnica em fevereiro de 1894. Os gastos per capita com o ensino superior mais que triplicaram (índice de 359) até 1906, perdendo fôlego nos anos seguintes até a instalação da Faculdade de Medicina e Cirurgia em 19137.

Figura 2

Despesa real e participação dos níveis de ensino, governo de São Paulo (1889-1920)
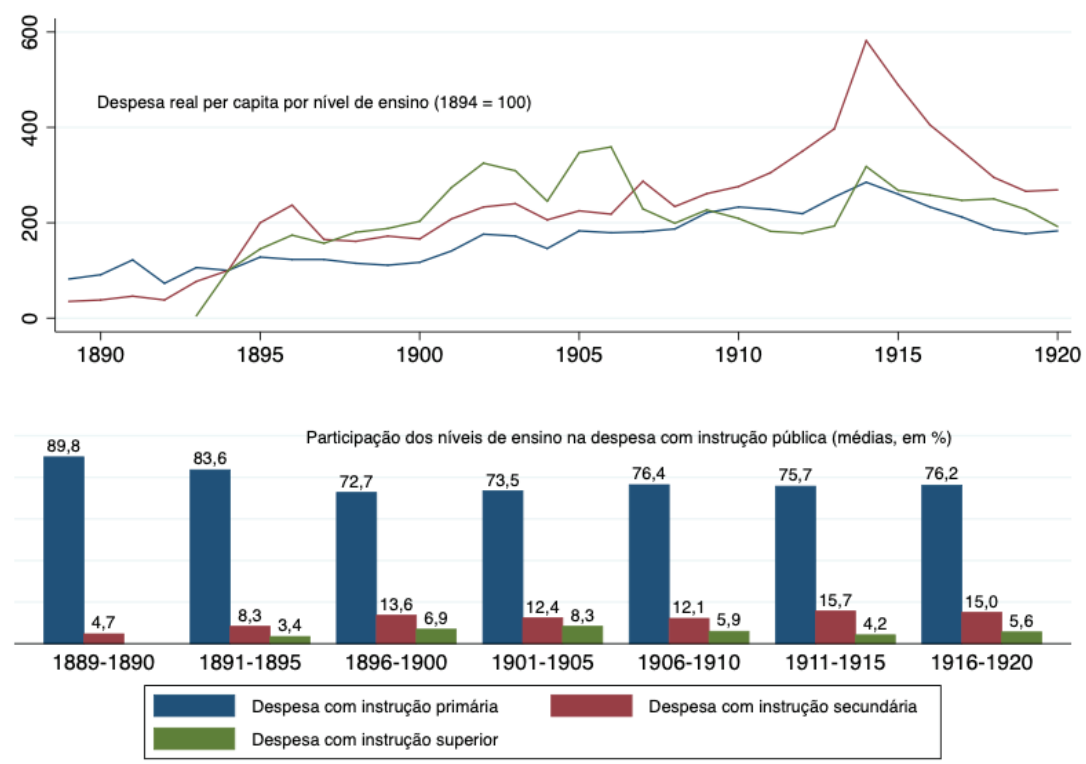

Fontes: São Paulo (1912:216; 1940:9-10)..

Nota: na parte (b) da Figura, além dos níveis de ensino citados, as despesas do estado incluíam ensino profissional, subvenções e despesas diversas. 
O acelerado crescimento das despesas com instrução secundária e a inauguração das escolas públicas superiores levaram, naturalmente, a um declínio relativo da instrução primária nas despesas totais com ensino público no Estado de São Paulo. Como mostra o segundo gráfico da Figura 2, a participação das escolas primárias nos gastos estaduais com instrução pública declinou de 89,8\% em 1889-1890 para uma média de 72,7\% entre 1896-1900, quando os efeitos combinados dos investimentos nas escolas secundárias (13,6\% do total) e superior $(6,9 \%)$ tiveram pleno efeito. Nos anos seguintes, as despesas com instrução primária mantiveram-se em torno da média de 75\%-76\% dos gastos com instrução pública em São Paulo.

O aumento do gasto per capita com instrução primária indicado por esses números conta apenas parte da história. Como vimos anteriormente, houve queda no comprometimento das receitas públicas com as escolas elementares nas primeiras décadas da República, em relação aos últimos dez anos do Império (Tabela 1). Por esse motivo, o aumento da despesa com instrução primária durante o período republicano pode ser considerado mais um efeito do excepcional crescimento das receitas tributárias na época do que a consequência de um maior empenho governamental na ampliação da oferta de vagas nas escolas. Podemos avaliar de forma mais precisa esse resultado recorrendo a um conceito de esforço fiscal vinculado à educação primária - o que Peter Lindert chamou de "primary-school support ratio" (Lindert, 2004:44-45). Esse conceito que podemos chamar de "esforço educacional" - leva em conta não apenas as despesas realizadas com instrução primária, mas também a receita arrecadada pelo governo relativamente à população, isto é, a capacidade de financiamento das despesas educacionais por parte do governo e dos contribuintes ${ }^{8}$. Formalmente,

$$
e s f_{n}=\frac{\operatorname{desp}_{n}}{\operatorname{mat}_{n}} / \frac{r e c_{n}}{p o p_{n}}
$$

em que:

esf $f_{n}=$ esforço educacional no ano $n$;

desp $p_{n}=$ despesa provincial com instrução primária no ano $n$;

$\mathrm{rec}_{n}=$ receita provincial total arrecadada no ano $n$;

mat $_{n}=$ número de alunos matriculados nas escolas públicas de instrução primária no ano $n$;

$\operatorname{pop}_{n}=$ população total do Estado de São Paulo no ano $n$. 
A Tabela 2 apresenta as médias quinquenais do esforço educacional na última década do Império e nos primeiros anos da República. Vê-se que os índices de esforço educacional chegaram a 8,8 e 8,2 nos dois quinquênios da década de 1880 . No período republicano, contudo, o esforço educacional despencou, alcançando na maioria do período analisado índices em torno da metade dos registrados nas últimas décadas do Império, como em 1891-1895 (3,5) ou 1911-1915 (4,1).

Tabela 2

Esforço educacional com instrução primária, São Paulo (1881-1920) (médias quinquenais)

\begin{tabular}{cc}
\hline Anos & Esforço educacional \\
\hline $1881-1885$ & 8,8 \\
$1886-1890$ & 8,2 \\
$1891-1895$ & 3,5 \\
$1896-1900$ & 4,6 \\
$1901-1905$ & 7,1 \\
$1906-1910$ & 5,7 \\
$1911-1915$ & 4,1 \\
$1916-1920$ & 4,0 \\
\hline
\end{tabular}

Fontes: dados de receita e despesa totais, despesas com instrução primária e matrículas conf. Colistete (2016: Apêndice B, Tabelas B-2, B-4 e B-6).

Nota: esforço educacional calculado de acordo com fórmula no texto.

Esses números demonstram que o notável aumento na receita fiscal de São Paulo a partir dos primeiros anos da República não foi acompanhado por elevação correspondente do gasto por aluno matriculado. Essa tendência foi alterada apenas brevemente em 1901-1905 (índice de 7,1), retornando aos níveis de esforço anteriores logo em seguida (Tabela 2).

Uma outra forma de avaliar esses resultados discrepantes é por meio de um exercício simples, formulando o seguinte contrafactual: qual seria a despesa com instrução primária se o mesmo esforço educacional nos últimos 5 anos fiscais do período monárquico fosse mantido durante as primeiras décadas do regime republicano em São Paulo? Formalmente:

$$
\operatorname{desp}_{n}=e s f_{\text {imp }} \frac{\operatorname{rec}_{n} \cdot \mathrm{mat}_{n}}{\operatorname{pop}_{n}},
$$


em que:

despn $=$ despesa contrafactual em mil-réis com instrução primária no ano n;

esfimp = média do esforço educacional nos últimos cinco anos fiscais do Império;

recn $=$ receita arrecadada em mil-réis no ano n;

matn = total de alunos matriculados nas escolas estaduais de instrução primária no ano n;

popn = população total do Estado de São Paulo no ano n.

As diferenças percentuais dos níveis contrafactual e efetivo do gasto com ensino primário (em valores de 1913) são apresentadas na Figura 3. Entre 1890 e 1899, o nível contrafactual da despesa com instrução primária mantém-se entre $57 \%$ e $152 \%$ acima da despesa efetivamente realizada durante a República, com exceção dos casos extremos em 1890 (-7\%) e 1892 (290\%). Ou seja, nos primeiros anos do regime republicano em São Paulo o esforço educacional observado foi substancialmente inferior ao registrado no último quinquênio do Império. Mesmo com o aumento nas despesas per capita no ensino básico no início da República, o excepcional aumento das receitas públicas não foi acompanhado por um compromisso equivalente com a instrução primária por parte do governo estadual.

Figura 3

Diferença entre despesa contrafactual e efetiva, Estado de São Paulo (1890-1920) (em porcentagem)

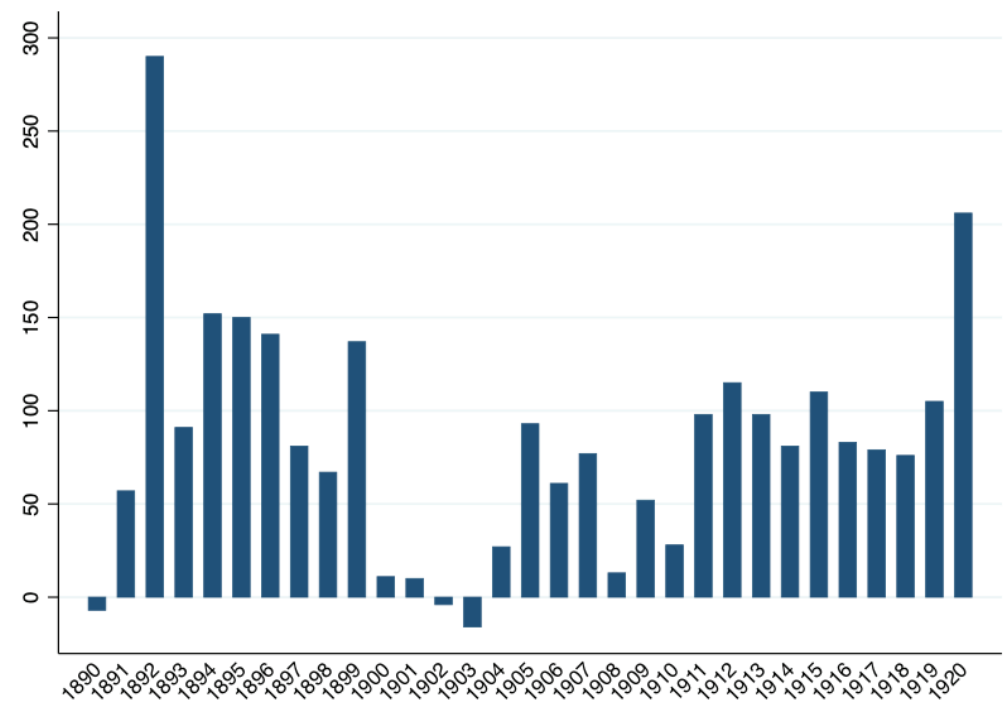

Fonte: Colistete (2016).

Nota: Estimativa do autor a partir da metodologia e dos dados citados no texto. 
Essa conclusão pode ser estendida ao restante do período até 1920. A abrupta redução do hiato entre despesa efetiva e contrafactual de 1900 a 1904, exibida na Figura 3, deve-se a uma circunstância atípica: no final de 1899, o governo estadual transferiu 547 escolas isoladas para as câmaras municipais, com uma redução entre 1899 e 1900 de 15.736 crianças matriculadas nas escolas estaduais ${ }^{9}$. Para auxiliar as câmaras na manutenção das escolas transferidas, o governo consignou um auxílio anual proporcional à população de cada município. Esse auxílio foi concedido nas três leis orçamentárias seguintes, até o ano de $1903^{10}$.

Deste modo, nos anos de 1900 a 1903, o governo estadual manteve a dotação às escolas das municipalidades, computando-a em suas despesas ordinárias, ao mesmo tempo que reduziu o número de alunos matriculados sob sua responsabilidade direta. Tal fato explica a elevação da despesa per capita com ensino primário do governo estadual e, por decorrência, a queda da diferença entre despesa contrafactual e efetiva entre 1900 e 1903, conforme a Figura 3. Nos anos seguintes, quando as matrículas estaduais voltaram a crescer e a subvenção às câmaras foi suspensa, a diferença entre esses níveis subiu novamente e a despesa contrafactual manteve-se, na maioria das vezes, entre $50 \%$ e $100 \%$ acima da despesa efetiva até o final da década de 1910 (Figura 3).

A estimativa da despesa contrafactual também é relevante para avaliar a diferença entre o gasto realizado e o necessário para que todas as crianças fora das salas de aulas pudessem frequentá-las. O exercício pode ser realizado a partir dos números estimados pelo Diretor de Instrução Pública do Estado de São Paulo, Oscar Thompson, em 1918. Thompson calculou as despesas adicionais para ampliação das cadeiras de instrução elementar necessárias para absorver 247.543 crianças de 7 a 12 anos que permaneciam sem instrução, em comparação com as 232.621 crianças que estavam matriculadas em escolas estaduais, municipais e particulares no Estado de São Paulo em 1918. Segundo o diretor, seria necessária a abertura de 4.951 novas cadeiras (razão de 1 professor para 50 alunos) que, com o vencimento anual de 2:460\$000 dos professores de escolas rurais, implicariam uma despesa extra de 11.882:400\$000 do orçamento estadual. Diante desse resultado, Thompson sustentou que seria "pecuniariamente impossível" que o Estado de São Paulo arcasse com o gasto adicional, que se 
somaria às já elevadas despesas de 15.115:940\$000 realizadas com a instrução primária pública na época (Thompson, 1918:20, 25).

A pergunta, então, que pode ser feita é: qual seria a despesa com instrução primária do governo estadual caso o mesmo esforço educacional nos últimos cinco exercícios fiscais do Império fosse replicado nas contas públicas de 1918? Tendo em vista que a diferença entre a despesa contrafactual e efetiva nesse ano foi de 75,5\%, a despesa hipotética com instrução primária no exemplo utilizado por Oscar Thompson seria de 26.530:590\$930 (1.75514 x 15.115:940\$000) $)^{11}$. Esse valor é praticamente idêntico ao que o Diretor da Instrução Pública calculou como sendo o total das despesas com instrução primária (26.998:340\$000) que permitiria a criação de 4.951 cadeiras para o ensino das crianças que se encontravam sem escola em 1918.

Em outras palavras, dada a elevação das rendas públicas estaduais observada no período, um esforço educacional equivalente ao que foi realizado nos últimos anos do Império seria capaz de alfabetizar praticamente a totalidade das crianças de 7 a 12 anos em São Paulo no final da década de 1910. O fato das despesas efetivas com instrução primária não terem sido suficientes para abranger toda a população infantil em idade escolar não pode ser atribuído à ausência absoluta de recursos ou à incapacidade financeira do governo estadual. A insuficiência de verbas estaduais para as escolas primárias deveu-se às decisões quanto à alocação das rendas públicas existentes durante as primeiras décadas da República.

Na década de 1880, as finanças de São Paulo foram pressionadas pelo crescimento acelerado das demandas por serviços públicos regulares e também por novas atribuições assumidas pelo governo provincial. A Figura 4 mostra que a Força Pública absorveu mais recursos $(19,5 \%)$ do que a instrução pública (14,5\%) em 1887. 
Figura 4

Gastos com serviços públicos na despesa pública total, Governo de São Paulo (1887-1920) (em porcentagem)

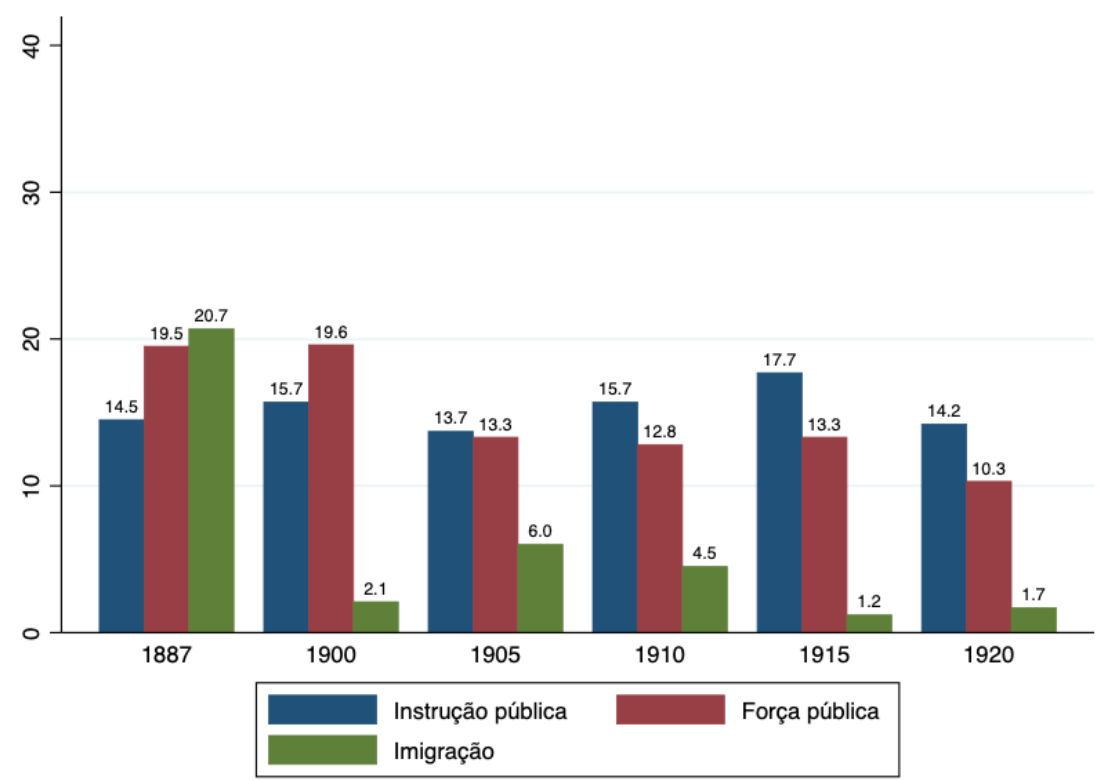

Fontes: São Paulo (1888; 1900); São Paulo, Annuario Estatistico, vários anos.

Com relação às despesas extraordinárias, os desembolsos com garantias de juros para as ferrovias foram significativos, mas declinaram relativamente aos percentuais registrados na década de 1870: enquanto no exercício de 1879-1880 os repasses às companhias ferroviárias alcançaram $16,8 \%$ das despesas provinciais, as transferências diminuíram para 5,2\% em 1882-1883 e 3,1\% em 1886-1887². Não obstante, outras despesas fora do orçamento ordinário cresceram rapidamente no período. A maior novidade foi o início dos subsídios para atrair imigrantes europeus para as fazendas de café. Começando com a lei $\mathrm{n}^{\circ} 36$ de 21 de fevereiro de 1881, que autorizou o governo a gastar 150 contos de réis com transporte de navio e construção de uma hospedaria para famílias vindas da Europa, as despesas com imigração subiram exponencialmente nos anos seguintes. No ano fiscal de 1881-1882, esses gastos representaram 1,5\% das despesas da província de São Paulo, mas em 1884-1885 saltaram para 8,7\% do total. A causa desse aumento foi a aprovação da lei provincial no 28 de março de 1884, que estabeleceu "a indenização das passagens" de navio de todos os membros (a partir de 3 anos) de famílias imigrantes da Eu- 
ropa e das Ilhas dos Açores e Canárias, bem como a criação de cinco núcleos coloniais, entre outras medidas ${ }^{13}$. Na Figura 4, vê-se que em 1886-1887 a imigração totalizou $20,7 \%$ dos gastos provinciais e ultrapassou o despendido com a instrução pública por larga margem. No ano seguinte, os gastos com imigração explodiram e atingiram nada menos do que 78,5\% dos dispêndios da Província, o que levou à contratação de empréstimos externos e lançamento de apólices do Tesouro para financiar as despesas extras ${ }^{14}$.

As consequências do crescimento dos recursos para a imigração foram notadas com clareza na época. Em 1888, o presidente da Província, Rodrigues Alves, do Partido Conservador, observou que as receitas arrecadadas eram mais que suficientes para financiar as despesas ordinárias, mas os gastos excepcionais com transporte e colocação de imigrantes eram responsáveis por um déficit explosivo. Em meio ao colapso do sistema de trabalho escravo, "o serviço de imigração" revestia-se de "caráter especial" e não podia deixar de ser realizado "por créditos especiais e com o recurso de operações de crédito", isto é, com recursos além das receitas ordinárias. Embora considerasse que "o estado econômico da Província" fosse melhorar no futuro "com o aumento natural da produção e consequente aumento da renda", em grande parte decorrente da própria imigração, Rodrigues Alves alertava que "o déficit a esperar" deveria "subir a quantia avultadíssima", como de fato ocorreu (São Paulo, 1888:38-39).

Nos últimos meses de 1887, o presidente da Província teve de recorrer a sucessivos empréstimos em conta corrente e ao lançamento de letras do Tesouro para "acudir a pagamentos urgentes" e permitir "o andamento regular dos serviços" da administração pública. Seria necessário não apenas que o Legislativo prosseguisse com suas autorizações ao governo para novos gastos com a imigração, mas também que permitisse a consolidação das dívidas em letras e em conta corrente, "evitando-se assim o prejuízo que infalivelmente se dará nos outros serviços provinciais" (São Paulo, 1888:38-39). Já em março de 1888, a Assembleia Legislativa aprovou a lei orçamentária do próximo exercício fiscal com uma autorização para que o governo levantasse 7 mil contos de réis para "consolidar a dívida flutuante e para a que contrair com o serviço de imigração"15. Os recursos foram obtidos com um empréstimo em Londres no mesmo ano, viabilizando o financiamento de despesas de 3.205 contos de réis (que equivaliam a 78,5\% da receita total) com a imigração no exercício de 1887-1888. 
Com os empréstimos internos e externos, portanto, o governo de São Paulo logrou preservar os recursos fiscais ordinários de um comprometimento insustentável com a política imigratória ${ }^{16}$.

Em suma, diante da necessidade considerada urgente de atração de imigrantes, os governos provinciais não hesitaram em ultrapassar todos os limites das rendas públicas e em recorrer a várias modalidades de endividamento interno e externo. Como ponderou em janeiro de 1889 o novo presidente da Província, Pedro Vicente de Azevedo, do Partido Conservador, "[t]alvez haja quem suponha um pouco aventuroso o nosso procedimento". Mas, prosseguia, "a emancipação dos cativos... veio nos colocar na contingência forçada de um acréscimo de trabalho no presente, de que não podemos isentar-nos". O Presidente defendeu que "era razoável sacar das futuras gerações que nos hão de suceder adiantamentos em conta dos bens que lhes havemos de legar". E concluiu com uma crença: "Tenho fé que não estamos fazendo um mau negócio, mesmo debaixo do ponto de vista econômico" (São Paulo, 1889:154). A disposição e capacidade de mobilizar recursos fiscais em larga escala para um objetivo considerado prioritário - a imigração europeia - mostrou que a restrição das rendas públicas era uma noção relativa. Que a instrução primária não foi elevada a uma condição similar à da imigração deveu-se mais às escolhas das políticas públicas do que à escassez de recursos no Estado de São Paulo.

Os sacrifícios impostos ao orçamento público pela concessão maciça de subsídios para a imigração europeia tiveram uma solução rápida e relativamente suave durante a década de 1890. A causa foi menos o efeito antecipado por Rodrigues Alves e Pedro Vicente de Azevedo, isto é, a elevação da produção e da renda resultante da entrada dos imigrantes, do que a própria continuidade do boom exportador e, sobretudo, a radical transformação das rendas públicas de São Paulo com a transferência do imposto de exportação para os estados sancionada pela Constituição de 1891. Como vimos anteriormente, a receita do governo de São Paulo quadruplicou em termos reais apenas entre os anos de 1890 e 1892. Ao mesmo tempo, passado o momento de maior pressão sobre o orçamento estadual, as despesas com o serviço de imigração estabilizaram-se e depois declinaram em termos absolutos ao final da década de 1890. Paralelamente, o desequilíbrio causado pelos gastos com a política imigratória foi transferido para a conta de juros e diferenças de câmbio, por meio do serviço dos empréstimos internos e externos para consolidação da dívida pública 
estadual. O resultado foi que as despesas correntes, relacionadas diretamente com a imigração europeia, declinaram (para 2,1\%) como proporção do total das despesas públicas em 1900, embora tenha subido novamente para $6 \%$ em 1905, conforme pode ser visto na Figura 4. Em 1910, o percentual da imigração ainda alcançava 4,5\%, diminuindo para 1,7\% das despesas estaduais em 1920. Enquanto isso, a instrução pública manteve aproximadamente sua participação no gasto público total no período (15,7\% em 1900 e 1910 e $14,2 \%$ em 1920), o que representava uma substancial elevação dos níveis absolutos da despesa, como vimos antes.

A situação excepcionalmente favorável das rendas públicas e suas implicações foram claramente notadas pelo governador Bernardino de Campos em 1896. No ano anterior, a receita estadual havia subido em termos reais mais de cinco vezes em relação ao arrecadado em 1890. Bernardino de Campos observava a respeito que os "resultados colhidos no exercício de 1895 ... dão a mais completa segurança da situação lisonjeira em que continuam as condições financeiras do Estado". "Tão notável expansão nos recursos ordinários da Receita", continuava o governador, "permitiu-me não só satisfazer todos os serviços contemplados no orçamento da Despesa, como a dar todo o impulso" aos serviços relacionados "ao bem-estar e ao progresso do Estado, como sejam a instrução pública, os trabalhos do saneamento e o suprimento de braços à agricultura". Bernardino de Campos atribuiu a situação das contas públicas ao "progresso real que tem tido o Estado" e às "vantagens que tem auferido com a descentralização política e administrativa do novo regime federativo" (São Paulo, 1896:74-75).

Naturalmente, o cenário auspicioso não era definitivo, como bem sabiam os membros do governo. Com a volatilidade dos preços internacionais e das receitas do café, as finanças públicas de São Paulo sujeitavam-se a mudanças bruscas, a despeito da tendência positiva no longo prazo. Logo após a Mensagem de Bernardino de Campos, São Paulo voltou a enfrentar dificuldades com a queda dos preços internacionais, o que levou o governo a buscar novas fontes de tributação. Além disso, a captação de empréstimos internos e externos para financiar as garantias de juros das companhias ferroviárias, a imigração em massa e, em seguida, a compra e estocagem de café tiveram como contrapartida uma rápida elevação dos compromissos com juros e diferenças de câmbio do Tesouro estadual. Enquanto em 1886-1887 os pagamentos dessa conta somavam 2,5\% da despesa pública da Província, as obri- 
gações subiram para 13,6\% em 1900, 19,3\% em 1910 e 20,2\% em $1920^{17}$. Para piorar, projetos ferroviários que não conseguiram restituir aos cofres estaduais os subsídios recebidos tornaram-se inadimplentes e tiveram de ser absorvidos pelo governo de São Paulo - caso da Estrada de Ferro União Sorocabana e Ituana. A encampação dessa companhia em 1905 deu origem à maior operação de empréstimo externo até então realizada pelo Estado de São Paulo, no valor de 8 milhões e 800 mil libras esterlinas (São Paulo, 1905:16-25).

Em diferentes momentos, os gastos com garantias de juros, imigração, juros e câmbio dos empréstimos pressionaram as demais despesas governamentais, inclusive a instrução primária. É possível utilizar aqui uma medida aproximada de quais itens e quanto dos gastos planejados foram sacrificados com as restrições financeiras provocadas pela garantia de juros, calculando o efeito ponderado da diminuição ou do aumento dos itens individuais das despesas públicas em relação ao orçamento aprovado pela Assembleia Legislativa ${ }^{18}$. No ano de 1905, por exemplo, as despesas ordinárias realizadas ficaram $4,7 \%$ acima do previsto no orçamento. As receitas totais subiram em relação ao ano anterior devido à liquidação de dívidas, às diferenças de câmbio e à renda da estrada de ferro Sorocabana, mas as receitas ordinárias caíram em especial devido à queda da arrecadação dos direitos de exportação do café (São Paulo, 1905:III-X).

Pelo lado das despesas, a grande maioria dos itens declinou, com algumas exceções como os gastos com Assembleia Legislativa, Socorros Públicos, Serviço de Imigração, Força Policial e Juros e Diferenças de Câmbio. Essa última conta consumiu 17,1\% das despesas ordinárias em 1905, tornando-se o maior item individual de dispêndio no exercício. Considerando o seu peso relativo nas despesas, o gasto com Juros e Diferenças de Câmbio acima do orçado teve o maior impacto positivo (164\%) para elevação das despesas públicas de São Paulo em 1905. A Assembleia Legislativa (10,4\%), a Força Policial (6,1\%) e o Serviço de Imigração $(3,3 \%)$ também contribuíram para aumentar as despesas ordinárias, mas com influência menor.

Por sua vez, várias categorias da despesa pública diminuíram em relação ao aprovado pela lei orçamentária para o ano de 1905. O ajuste recaiu especialmente sobre os recursos para instrução primária. Em vista de sua elevada proporção $(12,4 \%)$ nas despesas ordinárias, a contração no gasto das escolas primárias em relação ao orçado foi a 
que mais contribuiu (-24,5\%) para reduzir as despesas públicas do ano. Em seguida, vieram as obras públicas em geral, com $-14,2 \%{ }^{19}$. Deste modo, em meio às dificuldades vividas pelas exportações de café e pela arrecadação fiscal, as despesas com juros e diferenças de câmbio continuaram subindo e absorvendo parcelas crescentes do orçamento público. Outros itens, como imigração e força policial, também pressionaram as finanças estaduais. A instrução primária e as obras de infraestrutura, por sua vez, foram os serviços públicos que assumiram a maior parcela do ajuste em um contexto de instabilidade das rendas públicas.

Por fim, toda a análise até o momento baseou-se em dados de despesas das escolas mantidas pelo antigo governo provincial e, depois, estadual de São Paulo. A partir de 1887 os municípios passaram a investir na instrução elementar, utilizando inicialmente o imposto de capitação e o fundo escolar para as escolas primárias criados pela Lei no 81 de 6 de abril de 1887 e, a partir de 1892, empregando recursos próprios. Os municípios alcançaram, em 1901-1905, sua maior participação $(10,8 \%)$ no total das despesas públicas com instrução primária no Estado de São Paulo no período analisado, como pode ser conferido na Tabela 3.

O salto nas despesas das municipalidades ocorreu justamente entre 1899 e 1900 (3,8\% para 10,1\% do total dos gastos), quando houve a transferência das escolas isoladas pelo governo do estado. Esse fato sugere a possibilidade de que tenha havido dupla contagem nas despesas registradas nos municípios e as subvenções do governo do estado para as escolas transferidas. A título de exemplo, a câmara de Atibaia incluiu em seu orçamento para o ano fiscal de 1903-1904 a previsão de "Auxílio do governo às escolas provisórias", no valor de 2:525\$320, embora o auxílio não conste registrado em orçamentos anteriores de 1901-1902 e 1902-190320. Atibaia foi um dos municípios que mantiveram as despesas com escolas primárias mesmo após a supressão do imposto de capitação e do fundo escolar em 1892. No orçamento para 1893-1894, a câmara fixou o gasto de 300\$000 com a instrução pública ${ }^{21}$. No balanço do exercício de 1899-1900, a despesa de Atibaia com instrução foi de $881 \$ 500$, provavelmente com os vencimentos de um professor adjunto ${ }^{22}$. 
Tabela 3

Participação dos municípios nas despesas públicas em instrução primária, Estado de São Paulo (1894-1920) (médias quinquenais, em \%)

\begin{tabular}{cc}
\hline Anos & Despesas com instrução primária \\
\hline $1894-1895$ & 2,5 \\
$1896-1900$ & 4,5 \\
$1901-1905$ & 10,8 \\
$1906-1910$ & 8,5 \\
$1911-1915$ & 7,1 \\
$1916-1920$ & 4,8 \\
\hline
\end{tabular}

Fontes: 1889-1910: São Paulo (1912:216); 1911-1920: São Paulo, Anuário Estatístico, vários anos.

De qualquer forma, após o término das subvenções do governo estadual em 1903, as despesas dos municípios com instrução primária continuaram subindo em termos reais até 1912, quando ocorreu uma reversão da tendência e o início de um gradual declínio dos gastos locais com instrução. Esse resultado refletiu-se em queda da participação municipal nas despesas públicas com instrução primária, passando de 8,5\% em média em 1906-1910 para 4,8\% em 1916-1920, conforme a Tabela 3.

\section{MATRÍCULAS DO ENSINO PRIMÁRIO}

É possível agora examinar a evolução das matrículas nas escolas primárias estaduais de São Paulo entre 1880 e 1920. As maiores despesas com instrução primária resultaram em aumento da taxa de matrícula das crianças nas escolas durante a última década do Império. Como se vê na Tabela 4, a taxa de matrícula média das escolas elementares estaduais chegou a 16 por mil habitantes em 1881-1885 e atingiu 21 por mil habitantes entre 1886-1890. Se considerarmos apenas a população livre nos dois anos em que há informações sobre a composição da população de São Paulo nesses períodos, a tendência se mantém: a taxa de matrícula sobe de 17 em 1872 para 23 por mil habitantes livres em $1887^{23}$. Assim, o crescimento do número de crianças nas escolas superou significativamente a evolução da população livre nos últimos anos do Império. 
Tabela 4

Taxa de matrícula do ensino primário nas escolas provinciais/estaduais, São Paulo (1881-1920) (por 1.000 habitantes, médias quinquenais)

\begin{tabular}{cc}
\hline Anos & Taxa de matrícula \\
\hline $1881-1885$ & 16 \\
$1886-1890$ & 21 \\
$1891-1895$ & 18 \\
$1896-1900$ & 18 \\
$1901-1905$ & 16 \\
$1906-1910$ & 24 \\
$1911-1915$ & 37 \\
$1916-1920$ & 40 \\
\hline
\end{tabular}

Fontes: São Paulo, Relatório do Presidente da Província, vários anos; São Paulo (1895:137); São Paulo (1897:100); São Paulo, Annuario do Ensino, vários anos.

Já com relação aos primeiros anos da República, os dados oficiais indicam uma queda da taxa de matrícula em São Paulo: a taxa média declinou de 21 por mil habitantes em 1886-1890 para 18 nos quinquênios de 1891-1895 e 1896-1900 (Tabela 4). Desta forma, os primeiros anos do regime republicano parecem não ter sido favoráveis às matrículas das crianças nas escolas primárias frente ao aumento da população. Na verdade, essa conclusão é válida apenas para os anos 1891-1895, pois a média no quinquênio 18961900 sofre um declínio artificial devido à transferência - mencionada anteriormente - de 547 escolas primárias do governo estadual para as municipalidades, que produziu uma redução de 46.567 em 1899 para 30.831 matriculados em 1900 nas escolas primárias estaduais. Desconsiderando o ano atípico de 1900, a taxa de matrícula média alcançou 20 por mil habitantes em 1896-1899 ou 21 no ano de 1899, praticamente igualando, deste modo, os índices de matrícula do final do Império (Colistete, 2016: Apêndice B, Tabela B-6).

Com a transferência das unidades escolares para as câmaras em 1900, a média das matrículas nas escolas estaduais contraiu-se para 16 crianças por mil habitantes em 1901-1905. Mas com a expansão das escolas primárias estaduais após a transferência, as taxas de matrícula voltaram a subir rapidamente. A taxa média de matrícula chega a 24 já em 1906-1910 e 40 em 1916-1920, dobrando assim os níveis observados no final do Império (Tabela 4). De todo modo, foi somente 
após dez anos de governo republicano que as matrículas das escolas primárias alcançaram as taxas per capita registradas nos últimos anos do Império em São Paulo.

As taxas de matrícula nas escolas de São Paulo apresentam um panorama mais favorável da população escolar do que a realidade. A frequência nas escolas primárias manteve-se entre 70\%-75\% das matrículas computadas no início do ano letivo. Dados para o ano de 1907 das escolas primárias estaduais de São Paulo apontam para uma frequência de 77,5\% dos alunos matriculados. Em 1914, o índice ficou em $78,2 \%$. Ao final da década de 1910, o número oficial de alunos frequentes nas escolas mantidas pelo estado foi de apenas $60,8 \%$ do total das matrículas (Colistete, 2016: Apêndice B, Tabela B-6). Esses percentuais são geralmente menores do que os registrados no período do Império, que giraram em torno de 79\% em média. Se corretos, os números sugerem que as dificuldades enfrentadas pelos alunos para frequentar as escolas regularmente ao longo do ano persistiram ou podem mesmo ter se agravado no início do século XX.

A principal causa da descontinuidade na frequência dos alunos deveu-se ao trabalho na lavoura, sobretudo na cafeicultura. Com a diversificação econômica e a expansão das vilas e cidades, os núcleos urbanos passaram também a absorver trabalho infantil em escala crescente. A irregularidade das matrículas nas escolas teve duas características básicas. Primeiro, a frequência das crianças era sazonal, isto é, as faltas acumulavam-se durante os meses em que a demanda de trabalho era mais intensa devido à colheita de café e ao plantio de outras culturas. Segundo, ao fim do período de colheita, as matrículas nas escolas geralmente não retornavam aos níveis iniciais. A Figura 5 apresenta os percentuais mensais de frequência dos alunos em uma escola de bairro ao longo do ano letivo, no que parece ter sido uma situação recorrente vivida pela maior parte das escolas rurais ou próximas às áreas produtoras de café de São Paulo² . 
Figura 5

Frequência dos alunos de uma escola de São Paulo, c. 1907 (em porcentagem)

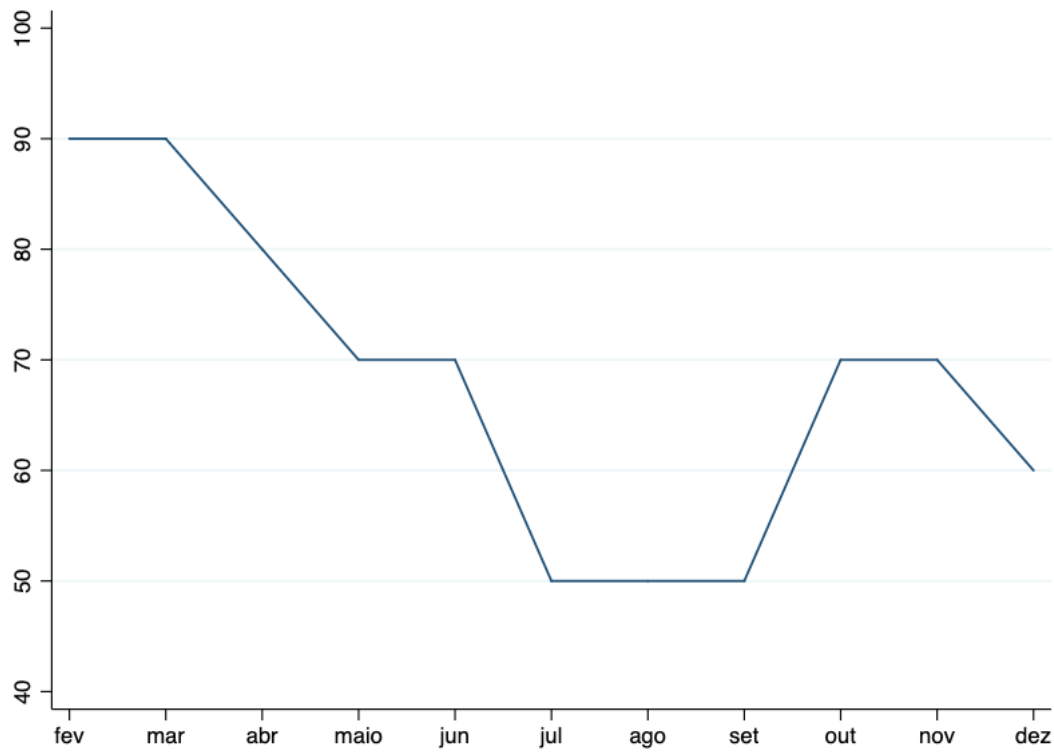

Fonte: São Paulo (1907-1908:39).

O exemplo dessa escola foi citado por João Lourenço Rodrigues, Inspetor Geral do Ensino de São Paulo, em seu Relatório de 1907-1908. Com percentual de $90 \%$ nos meses de fevereiro e março, a frequência dos alunos caiu para $50 \%$ entre julho e setembro, sem retornar ao alcançado no início do ano letivo. Nas palavras de Lourenço Rodrigues, a escola citada representava um caso comum, em que "a matrícula é relativamente boa e a frequência pequena e oscilante". Os percentuais mais baixos ocorriam "nos meses de julho, agosto e setembro, que, salvo engano, marcam a principal época da colheita do café e da plantação das roças". Para o Inspetor de Ensino, a mudança dessa situação era improvável: "Para esta infrequência, força é reconhecer, não há remédio possível. As famílias emigram para os centros de trabalho agrícola e isso traz, como consequência, o despovoamento periódico das escolas" (São Paulo, 1908/1909:39-40).

Vejamos agora qual foi a situação das matrículas nas escolas primárias mantidas pelas municipalidades de São Paulo. As estatísticas das escolas municipais aparentemente mais confiáveis somente estão disponíveis a partir de 1908. Nesse ano, as câmaras possuíam 12.207 crianças registradas em suas escolas elementares, o que correspondia a $14,8 \%$ 
do total das matrículas em escolas públicas primárias do estado (Colistete, 2016: Apêndice B, Tabela B-12). O crescimento das matrículas nas localidades foi irregular e, em 1919, o seu nível absoluto era apenas $24 \%$ (15.090 crianças) superior ao observado em 1908, representando $7,2 \%$ do total das vagas públicas no ensino primário. É possível, no entanto, que esses dados estejam subestimados, pois referem-se apenas aos números relatados por uma parte das câmaras municipais à Diretoria de Instrução Pública estadual. Em 1917, por exemplo, dos 188 municípios então existentes no Estado de São Paulo, foram coletadas informações oficiais de somente 57 deles, somando 343 escolas. Outros 33 municípios declararam nesse ano que não possuíam escolas, restando, portanto, 98 municípios para os quais não havia informações. Um ano antes, os dados oficiais divulgados referiram-se a apenas 175 escolas, quase metade do registrado em 1917 (São Paulo, 1917b:288-290).

Apesar de suas limitações, é provável que os números oficiais indiquem pelo menos a tendência de evolução das matrículas municipais no período, que aparentemente não acompanhou a expansão em $175 \%$ das matrículas primárias estaduais entre 1908 e 1920. O baixo crescimento das matrículas sob responsabilidade das câmaras municipais, se verdadeiro, levou à queda de sua participação na oferta de instrução primária pública no estado - média de 12,8\% em 19081910 para 7,3\% em 1916-1920, conforme Tabela 5. Esses dados levam a crer que a rápida expansão das escolas municipais constatada nos primeiros anos da República perdeu fôlego e reverteu a tendência de crescimento já na década de 1910.

Tabela 5

Participação dos municípios nas matrículas públicas da instrução primária, Estado de São Paulo (1894-1920) (médias, em \%)

\begin{tabular}{cc}
\hline Anos & Matrículas da instrução primária \\
\hline $1908-1910$ & 12,8 \\
$1911-1915$ & 8,6 \\
$1916-1920$ & 7,3 \\
\hline
\end{tabular}

O terceiro segmento na provisão de instrução primária em São Paulo era constituído pelo ensino particular. Da mesma forma que as escolas municipais, os dados oficiais do ensino privado são limitados e incompletos. Após os problemas com o levantamento das informações sobre as matrículas das escolas privadas após 1869, o governo 
provincial voltou a receber informações sobre essas escolas na década de 1880, mas ainda assim de forma incompleta e esporádica. $\mathrm{O}$ problema continuou durante a República. No Relatório do Inspetor Geral do Ensino de 1907-1908, por exemplo, as únicas informações citadas sobre o ensino privado referiam-se às escolas estrangeiras instaladas na capital, calculadas "em cerca de cem estabelecimentos", com "mais de seis mil crianças" matriculadas. Somente existiam números mais precisos com relação a uma parte desse total. A "Federação Italiana" (Federazione Scolastica) forneceu estatísticas de 5.060 alunos e alunas matriculados em 63 escolas da Capital, a maioria vinculada à Federazione (São Paulo, 1908:43-47, 377-81) ${ }^{25}$.

Em 1916, a Diretoria de Instrução Pública tinha conhecimento de 234 escolas particulares no Estado de São Paulo, enquanto em 1917 o número elevou-se para 567 devido "ao esforço dos srs. inspetores" para identificação de estabelecimentos privados por ordem governamental. A motivação para o registro mais completo da situação do ensino particular no estado deveu-se ao rompimento de relações diplomáticas do Brasil com a Alemanha no início de 1917 e a declaração de guerra aos países do Eixo em outubro daquele ano. Como uma parte significativa da instrução particular era oferecida em escolas estrangeiras, a Diretoria de Instrução Pública passou a preocupar-se com esses estabelecimentos e a acompanhar e fiscalizar de forma mais estreita o ensino oferecido nas escolas étnicas na capital e no interior de São Paulo (São Paulo, 1917a:291-341; 1918:430-58; 1919:111-13)²6.

Uma parcela elevada das matrículas das escolas particulares pertencia aos estabelecimentos destinados aos imigrantes e seus descendentes. Daquelas 567 escolas particulares de todos os níveis de ensino que a Diretoria de Instrução Pública identificou no Estado de São Paulo em 1917, havia 465 brasileiras reunindo 35.101 alunos matriculados. Das 102 escolas estrangeiras, 49 eram italianas com 6.882 alunos; 37 alemãs com 3.387 alunos; 6 americanas com 1.676 alunos; 3 francesas com 399 alunos; 4 portuguesas com 304 alunos, 1 inglesa com 185 alunos e 2 suíças com 62 alunos. A distribuição por nacionalidades não é exata quando comparada aos dados da tabela que acompanha a estimativa, mas os números dão uma ideia aproximada da diversidade nacional das escolas estrangeiras, com predomínio absoluto dos estabelecimentos de origem italiana e alemã, seguidos pelos americanos. No total, a Diretoria calculava que 10.386 alunos estavam matriculados no ensino primário e 2.473 alunos nos demais 
níveis de ensino das escolas particulares (São Paulo, 1917b:295, 336$41)^{27}$. Esse número de crianças que estudavam nas escolas primárias estrangeiras correspondia a $21,8 \%$ do total das matrículas nas escolas particulares do Estado de São Paulo em $1917^{28}$.

A Figura 6 traz a participação das escolas particulares e públicas nas matrículas da instrução primária em São Paulo entre 1908 e 1920. Vê-se que as escolas estaduais dominaram a oferta do ensino primário no estado, elevando sua participação de 62,7\% em 1908 para 74\% em 1914 e 76,7\% em 1920. As escolas municipais, como foi notado anteriormente, tiveram queda acentuada no total das matrículas do ensino primário de $11,1 \%$ em 1908 para $6 \%$ em 1920 . No início do período, cerca de $26,2 \%$ das vagas do ensino elementar eram oferecidos pelos estabelecimentos particulares, percentual esse que pode ter sido ainda maior devido à imprecisão dos registros oficiais. Ao longo do tempo, contudo, a participação das escolas privadas declinou diante da expansão mais rápida do sistema de escolas primárias estaduais. Apesar disso, os estabelecimentos particulares mantiveram uma participação substancial (em torno de $20 \%$ ) e superior à das municipalidades (cerca de 6\%) na oferta de instrução primária durante e após a Primeira Guerra Mundial em São Paulo.

Figura 6

Matrículas nas escolas primárias públicas e particulares, Estado de São Paulo (1908-1920) (em porcentagem)

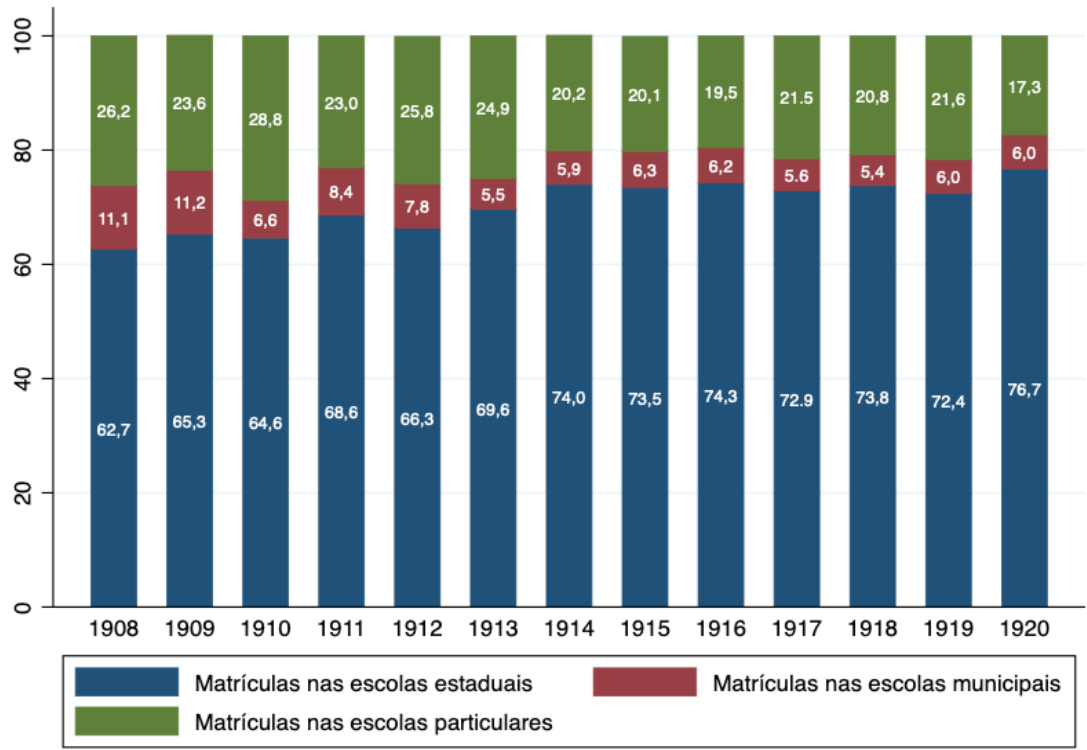

Fonte: São Paulo, Annuario do Ensino, vários anos. 
Por fim, é possível ainda avaliar o efeito combinado da expansão das escolas primárias estaduais, municipais e particulares nas taxas de matrícula do Estado de São Paulo no período. Considerando-se primeiramente os dados das escolas públicas estaduais e municipais, a Tabela 6 mostra que, nas três últimas décadas do século XIX, São Paulo ultrapassou as taxas médias de matrícula per capita do Brasil como um todo, passando de 11 crianças matriculadas por mil habitantes em escolas públicas em 1870 para 20 crianças por mil habitantes em 1890 - em comparação com os índices de 12 em 1870 e 16 em 1890 do Brasil.

Tabela 6

Taxa de matrícula da instrução primária (1870-1920) (por 1.000 habitantes)

\begin{tabular}{cccccccc}
\hline Anos & $\begin{array}{c}\text { São } \\
\text { Paulo }\end{array}$ & Brasil & Argentina & Portugal & Itália & Alemanha & $\begin{array}{c}\text { Estados } \\
\text { Unidos }\end{array}$ \\
\hline 1870 & $11(13)$ & $12(14)$ & 52 & 24 & 64 & 146 & 183 \\
1890 & $20(21)$ & $16(19)$ & 68 & 47 & 74 & 171 & 224 \\
1910 & $27(34)$ & $24(30)$ & 102 & 45 & 90 & 164 & 197 \\
1920 & $46(63)$ & $30(41)$ & 127 & 53 & 111 & 146 & 190 \\
\hline
\end{tabular}

Fontes: Brasil e São Paulo: 1870 - para São Paulo, Colistete (2016: Apêndice B, Tabelas B-6 e B-8); para Brasil, Brasil (1875: Anexo 2, ano de 1871); 1890 - Almeida (1889:1.017-54), ajustado com matrículas de São Paulo em 1889, Colistete (2016: Apêndice B, Tabela B-6); 1910 - Brasil (1927:11); 1920 - Brasil (1927:1011). Outros países: Colistete (2016: cap. 1).

Notas: dados de escolas públicas (estaduais e municipais), com soma das matrículas privadas entre parênteses. Os números referem-se aos anos indicados na tabela ou próximos. Para Brasil e São Paulo, os dados são relativos aos anos de 1870 (São Paulo), 1871 (Brasil), 1888-1889, 1907 e 1920. As taxas foram calculadas com as populações dos recenseamentos de 1872, 1890 e 1920. Para 1910, foi utilizada a estimativa de população em Brasil (s.d.:1.294-96). A proporção das matrículas públicas e privadas do Brasil em 1871 foi estimada com os resultados de 1874 .

Nas duas décadas seguintes, as matrículas públicas em São Paulo (27 em 1910) mantiveram-se acima da média do país (24), embora seu crescimento tenha sido inferior ao nacional. Já na década de 1910, a expansão das matrículas públicas em São Paulo foi muito mais rápida (4,2\% ao ano) do que no Brasil como um todo (1,7\% a.a.). Em 1920, São Paulo distanciou-se da média nacional e obteve a terceira maior taxa de matrícula das escolas primárias públicas (46), atrás da Capital Federal (72) e de Santa Catarina $(48)^{29}$. O quadro não é alterado quando são incluídas as matrículas nas escolas particulares, situação em que São Paulo alcançou 63 crianças matriculadas por 1.000 habitantes, frente a 41 crianças na média brasileira ${ }^{30}$.

Não obstante, apesar de seu rápido crescimento e destaque em termos nacionais, as taxas de matrícula do Estado de São Paulo conti- 
nuavam, em 1920, próximas ou inferiores aos índices dos países mais atrasados educacionalmente na Europa, como Portugal (53). No mesmo ano, as matrículas per capita estaduais atingiam cerca da metade do índice da Argentina, a nação-líder na América Latina em termos educacionais (Tabela 6). A convergência em relação aos indicadores internacionais foi lenta e limitada. $\mathrm{O}$ atraso do ensino primário manteve-se persistente, a despeito da prosperidade econômica trazida com o café e da criação de escolas e novas organizações da instrução pública no período.

\section{CONCLUSÕES}

Os últimos anos do Império e, em particular, as primeiras décadas da República foram um período intenso de reformas e mudanças da educação primária no Brasil. Como tem sido ressaltado pela historiografia, o caso de São Paulo é ilustrativo e o maior exemplo da reestruturação do sistema escolar, das importantes inovações organizacionais, como a criação dos grupos escolares, e do rápido crescimento de despesas e matrículas nas escolas públicas ocorridos na época. Os dados apresentados anteriormente confirmam essa percepção, com a despesa real per capita e a taxa de matrícula crescendo substancialmente em São Paulo, a ponto de o estado tornar-se um dos líderes da educação primária do país na década de 1920 - contrastando com seu atraso em relação ao restante do Brasil em meados do século XIX.

Essa é, no entanto, apenas parte da história. Desde a última década do século XIX os gastos com instrução primária em São Paulo cresceram em ritmo significativamente menor do que as receitas fiscais, beneficiadas como foram essas últimas pelo aumento das vendas de café no exterior e pela transferência do imposto de exportação para os estados após a Constituição de 1891. O descompasso entre rendas públicas e gastos com instrução primária refletiu o menor empenho do setor público para atender as crianças que permaneciam fora das salas de aula. Realmente, o esforço fiscal destinado à educação elementar durante a República girou em torno da metade do realizado durante os últimos dez anos do Império. Portanto, o fato de mais de $50 \%$ das crianças em idade escolar continuarem sem acesso ao ensino primário no Estado de São Paulo ao final da década de 1910 não se devia estritamente a restrições orçamentárias ou à inexistência de recursos públicos. 
A defasagem das despesas com instrução primária diante da evolução das receitas públicas ajuda a explicar a distância das taxas de matrículas de São Paulo em relação aos indicadores internacionais, apesar de o estado ter se tornado um dos líderes nacionais da instrução primária já em 1920. Na época, a posição relativa do Brasil frente a outros países não se distinguia substancialmente do registrado em meados do século XIX, mantendo-se entre aquelas nações com os piores indicadores educacionais do mundo. A situação era similar em São Paulo, cuja convergência em relação aos indicadores dos países líderes da instrução primária foi limitada e desigual, mesmo com as condições excepcionais de acumulação da riqueza privada e das rendas públicas produzidas pelo sucesso da economia cafeeira. A crônica deficiência da educação primária tornou-se, então, uma das características mais marcantes da acelerada diversificação urbana e industrial já vivida por São Paulo na época e que se aprofundaria nas décadas seguintes.

(Recebido para publicação em 3 de setembro de 2016) (Aprovado para publicação em 12 de fevereiro de 2019)

\section{NOTAS}

1 Lei de 15 de outubro de 1827 (Brasil, 1878:71-73); Lei no 16 de 12 de agosto de 1834, art. 10 e 11, (Brasil, 1866); Leal (1915:117-18, 174-75).

2 Ver, por exemplo, Reis Filho (1995); Souza (1998); Hilsdorf (2011); Love (1982:132-35).

3 Os dados desses dois estados não são apresentados na Figura 1.

4 Com dados similares de estados e províncias no Brasil, Aldo Musacchio e colegas identificaram uma relação positiva entre desempenho exportador e gastos per capita com instrução pública. Ver Musacchio, Fritscher e Viarengo (2014).

5 A estimativa consistiu em calcular o coeficiente das despesas previstas com instrução primária em relação ao total da instrução pública no orçamento provincial aprovado na Assembleia Legislativa para um determinado ano e multiplicar esse coeficiente pela despesa efetiva com instrução pública. Ver Colistete (2016) para os dados originais.

6 Os dados anuais encontram-se em Colistete (2016: Apêndice B, Tabelas B-2 e B-4).

7 A Faculdade de Medicina foi criada por lei em 19 de dezembro de 1912 e instalada oficialmente em 2 de abril de 1913, conf. São Paulo (1914:79). Embora não tratadas aqui, o governo de São Paulo também abriu escolas de ensino profissional a partir de 1911. Antes disso, o governo subvencionava o Liceu de Artes e Ofícios, localizado na capital. Ver Moraes (2001:172-188).

8 Sobre o conceito de esforço fiscal e suas diferentes medidas, ver Bird (1978:33-61); Ahmad e Stern, 1989:1017-19). Idealmente, seria mais adequado utilizar os gastos com instrução normalizados pela população em idade escolar (em vez do número de crianças 


\section{Renato Perim Colistete}

matriculadas) e a renda per capita (em vez da receita fiscal per capita), mas os dados para esse cálculo não estão disponíveis para a maior parte dos anos do período aqui tratado.

9 Conf. São Paulo (1901:17). Para o número de crianças matriculadas, ver São Paulo (1913:554). Esta última fonte registra um número menor (216) de escolas do que o citado na Mensagem de Rodrigues Alves em 1901.

10 São Paulo, Lei no 686, 16/9/1899, art. 2o, § 11, e Disposições Permanentes, art. 32;

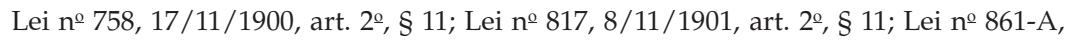
16/12/1902, art. 2으, § 11; Lei ํo 896, 30/11/1903, art. 2º, § 13 .

11 A estimativa é feita sobre uma base modesta, pois o ano de 1918 teve a menor diferença percentual entre despesa contrafactual e efetiva nos anos de 1911 a 1920, como pode ser verificado na Figura 3.

12 Balanço da Receita e Despesa do Estado de São Paulo, 1882-1883, Tabela no 21, anexo de São Paulo (1884); Balanço da Receita e Despesa do Estado de São Paulo, 1886-1887, Tabela no 19, anexo de São Paulo (1888).

13 São Paulo, Lei no 28, 29 de março de 1884. Sobre a política imigratória em São Paulo, Grossi (1905:396-98); Beiguelman (1968a:99-116; 1968b:145-157); Hall (1969:92-115); Holloway (1984).

14 São Paulo (1889), anexo "Despeza realisada com o Serviço de Immigração".

15 São Paulo, Lei no 55, 22 de março de 1888, art. 3ํ․

16 São Paulo (1889:150-51) e anexo "Despeza realisada com o Serviço de Immigração".

17 Conf. as mesmas fontes da Figura 4.

18 O método para decompor a contribuição ponderada de cada item da despesa é baseado na análise de shift share setorial, conf. Reynolds (1980: cap. 3). A soma dos percentuais positivos e negativos de cada item é igual a 100\%. Os resultados dos cálculos podem ser solicitados ao autor.

19 Como observado, os percentuais positivos e negativos somam 100\%. Ver Reynolds (1980: cap. 3).

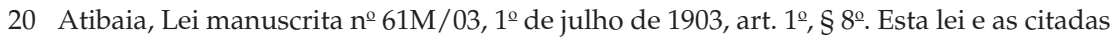
a seguir estão disponíveis na página da Prefeitura de Atibaia, http:/ / www.prefeituradeatibaia.com.br/sislegis/legislacao.

21 Atibaia, Lei manuscrita no 2M/93, 4 de julho de 1893.

22 Atibaia, Lei manuscrita no 35M/01, 1o de julho de 1901 .

23 Para os dados de matrícula nesses anos, Colistete (2016: Apêndice B, Tabela B-6). Números da população livre e escrava, conf. Brasil (1876); Commissão Central de Estatistica (1888). Nos dois casos, foram usadas as edições críticas de Bassanezzi (1998/1999).

24 A Figura 5 é uma reprodução adaptada do gráfico apresentado em São Paulo (1907/1908:39).

25 Sobre as escolas italianas em São Paulo, Mimesse (2012). 
26 Sobre as escolas étnicas em São Paulo, ver Alves (2007); Bezerra (2001; 2007); Grininger (1991); Souza (2014: cap. 3-4). Para uma análise geral dessas escolas no Brasil, Kreutz (2007:347-370; 2000:159-176).

27 As somas dos números de matriculados reproduzidos no documento são divergentes (12.985 no texto e 12.859 na tabela). Optou-se pelo número que consta da tabela original.

28 As matrículas na instrução primária das escolas privadas foram de 47.657 crianças em 1917.

29 Calculado de Brasil (1927:10-11).

30 Ibidem. Índices com as matrículas privadas entre parênteses. O Rio Grande do Sul alcançou índice (63) idêntico ao de São Paulo no total das matrículas em 1920. 


\section{REFERÊNCIAS BIBLIOGRÁFICAS}

AHMAD, Ehitsham; STERN, Nicholas. (1989), “Taxation for developing countries”. in: H. Chenery e T.N. Srinivasan (eds.), Handbook of development economics. Amsterdam, Elsevier, vol. II, pp. 1017-1019.

ALMEIDA, José Ricardo Pires de. (1889), L'instruction publique au Brésil. Histoire et Législation. Rio de Janeiro: Imp. G. Leuzinger \& Filhos.

ALVES, Silvane R. L. (2007), A Instrução Pública em Indaiatuba: 1854-1930. Contribuição para a história da educação brasileira. Dissertação (Mestrado em Educação), Universidade Estadual de Campinas, Campinas.

BASSANEZZI, Maria Silvia C. Beozzo (org.). (1998/1999), São Paulo do passado: dados demográficos. Campinas: Nepo/Unicamp.

BEIGUELMAN, Paula. (1968a), "A grande imigração em São Paulo I". Revista do Instituto de Estudos Brasileiros, n. 3, pp. 99-116.

. (1968b), "A Grande Imigração em São Paulo II". Revista do Instituto de Estudos Brasileiros, n. 4, pp. 145-157.

BEZERRA, Maria Cristina S. (2001), Imigração, educação e religião: um estudo históricosociológico do Bairro dos Pires de Limeira, uma Comunidade Rural de Maioria TeutoBrasileira. Dissertação (Mestrado em Educação), Universidade Estadual de Campinas, Campinas.

. (2007), Educação étnica: a pluralidade das propostas educacionais de origem germânica no Estado de São Paulo. Tese (Doutorado em Educação), Universidade Estadual de Campinas, Campinas.

BIRD, Richard. (1978), "Assessing tax performance in developing countries: a critical review of the literature", in: J. F. J. Toye (ed.), Taxation and economic development. twelve critical studies. London: Frank Cass, pp. 33-61.

ENGERMAN, Stanley L.; MARISCAL, Elisa; SOKOLOFF, Kenneth L. (2009), “The evolution of schooling in the Americas, 1800-1925," in: D. Eltis; F. D. Lewis; K. L. Sokoloff, Kenneth L. (eds.), Human Capital and Institutions. A Long-Run View. Cambridge: Cambridge University Press, pp. 93-142.

GRININGER, Valdemar. (1991), Imigração Suíça em São Paulo: A História da Colônia Helvetia. Dissertação (Mestrado em História), Universidade Estadual de Campinas, Campinas.

GROSSI, Vincenzo Grossi. (1905), Storia della colonizzazione europea al Brasile e della emigrazione italiana nello Stato di S. Paulo. Roma: Oficina Poligrafica Romana.

HALL, Michael. (1969), The origins of mass immigration in Brazil, 1871-1914. Tese (Doutorado em História), Columbia University, New York.

HILSDORF, Maria Lucia. (2011), História da educação brasileira: leituras. São Paulo: Cengage Learning.

HOLLOWAY, Thomas. (1984), Imigrantes para o Café. Café e Sociedade em São Paulo, 18861934. Rio de Janeiro: Paz e Terra. 
KREUTZ, Lúcio. (2000), “Escolas comunitárias de imigrantes no Brasil: Instâncias de coordenação e estruturas de apoio". Revista Brasileira de Educação, n. 15, pp. 159-176.

. (2007), "A educação de imigrantes no Brasil", In: E. M. T. Lopes; L. M. Faria Filho (eds.). 500 anos de educação no Brasil. Belo Horizonte: Autêntica, pp. 347-370.

LEAL, Aurelino. (1915), Historia Constitucional do Brazil. Rio de Janeiro: Imprensa Nacional.

LINDERT, Peter. (2004), Growing Public. Social spending and economic growth since the Eighteenth Century. Cambridge: Cambridge University Press, vol. II.

LOVE, Joseph. (1982), São Paulo na Federação Brasileira, 1889-1937. São Paulo: Paz e Terra.

MIMESSE, Eliane. (2012), “A Questão da nacionalização do ensino: escolas italianas na cidade de São Paulo no início do século XX". Revista HISTEDBR On-line, v. 12, n. 48, pp. 286-295.

MORAES, Carmen Sylvia Vidigal. (2001), "Instrução 'popular' e ensino profissional: uma perspectiva histórica,". In: D. G. Vidal; M. L. S. Hilsdorf (eds.). Brasil 500 Anos. Tópicas em História da Educação. São Paulo: Edusp. pp. 172-188.

MUSACCHIO, Aldo; FRITSCHER, André Martínez; VIARENGO, Martina. (2014), “Colonial institutions, trade shocks, and the diffusion of elementary education in Brazil, 1889-1930". Journal of Economic History, v. 74, n. 3, pp. 730-766.

REIS FILHO, Casemiro. (1995), A educação e a ilusão liberal. Origens da escola pública paulista. Campinas: Autores Associados.

REYNOLDS, Clark. (1980), A shift-share analysis of regional and sectoral productivity growth in Contemporary Mexico. Laxenburg: International Institute for Applied Systems Analysis.

SOUZA, Bruno Gabriel Wietzel de. (2014), The combined effect of institutions and human capital for economic development: A case study of german immigration to São Paulo, Brazil, 1840-1920. Dissertação (Mestrado em Economia do Desenvolvimento), Georg-August-Universität Göttingen, Göttingen.

SOUZA, Rosa Fátima. (1998), Templos de civilização: a implantação da escola primária graduada no Estado de São Paulo, 1890-1910. São Paulo: Editora Unesp.

THOMPSON, Oscar. (1918), “O Analphabetismo no Estado de S. Paulo”. São Paulo, Annuario do Ensino do Estado de São Paulo - 1918. São Paulo, Augusto Siqueira \& C., pp. 19-44.

\section{Documentos}

BRASIL. (1876), Recenseamento da população do império do Brasil de 1872. Rio de Janeir: Typ. de Leuzinger e Filhos, vol. I.

(1875), Relatorio e Trabalhos Estatisticos apresentados ao Illm. e Excm. Sr. Conselheiro Dr. João Alfredo Corrêa de Oliveira, Ministro e Secretario d'Estado dos Negocios do Imperio, pelo Director Geral Interino Dr. José Maria do Coutto, em 30 de abril de 1875. Rio de Janeiro: Typographia de Pinto, Brandão \& Comp.

(1866), Collecção das Leis do Imperio do Brazil - 1834. Parte I. Rio de Janeiro, Typographia Nacional. 


\section{Renato Perim Colistete}

(1878), Collecção das Leis do Imperio do Brazil - 1827. Parte I. Rio de Janeiro: Typographia Nacional.

. (1916). Estatistica da Instrucção. Estatistica Escolar. Vol. I. Rio de Janeiro: Typographia da Estatistica.

. (1927), Directoria Geral de Estatistica. Ensino Primario. Rio de Janeiro: Typ. da Estatistica.

. (s.d.), Anuário Estatístico do Brasil, 1939/1940. Rio de Janeiro: IBGE.

COMMISÃO CENTRAL DE ESTATISTICA. (1888), A Provincia de São Paulo em 1888. Relatorio apresentado ao Exm. Sr. Presidente da Provincia de S. Paulo pela Commissão Central de Estatistica. S. Paulo: Typographia King.

SÃO PAULO. (1884), Falla dirigida á Assembléa Legislativa Provincial de S. Paulo na abertura da $1^{a}$ sessão da $25^{a}$ legislatura em 16 de janeiro de 1884 pelo Presidente Barão de Guajará. S. Paulo: Typ. da Gazeta Liberal.

(1888), Relatorio apresentado ao Illm.e Exm. Snr. Dr. Francisco de Paula Rodrigues Alves, Presidente da Provincia de S. Paulo, pelo Inspector do Thesouro Provincial, Bacharel José Joaquim Cardoso de Mello. São Paulo, Typographia a vapor de Jorge Seckler.

. (1889), Relatorio apresentado á Assembléa Legislativa Provincial de São Paulo pelo Presidente da Provincia, Dr. Pedro Vicente de Azevedo, no dia 11 de janeiro de 1889. São Paulo, Typographia a Vapor de Jorge Seckler \& Comp.

(1896), Mensagem enviada ao Congresso Legislativo a 7 de abril de 1896, por Bernardino de Campos, Presidente do Estado. s.c., s.ed.

. (1900), Relatorio apresentado ao Dr. Francisco de Paula Rodrigues Alves, Presidente do Estado, pelo Dr. Francisco de Toledo Malta, Secretario da Fazenda, Anno de 1900. $2^{\mathrm{a}}$ edição, São Paulo: Typ. do "Diario Official".

. (1901), Mensagem enviada ao Congresso do Estado a 7 de abril de 1891 pelo Dr. Francisco de Paula Rodrigues Alves, Presidente do Estado. São Paulo: Typographia do "Diario Official".

- (1907-1908), Relatorio apresentado ao Exmo. Sr. Secretario dos Negocios do Interior pelo Professor João Lourenço Rodrigues, Inspector Geral do Ensino. Annexo I, 1907-1908, anexo de São Paulo. (1908), Relatorio apresentado ao Exmo. Snr. Dr. Jorge Tibiriçá, Presidente do Estado de São Paulo, pelo Secretario de Estado dos Negocios do Interior Dr. Gustavo de Oliveira Godoy. Anno de 1907-1908. São Paulo: Duprat \& Comp.

(1907-1908), Annuario do Ensino do Estado de São Paulo - 1907-1908. São Paulo: Typ. Augusto Siqueira \& C.

. (1912), Annuario Estatistico de São Paulo - 1910. São Paulo: Duprat \& Cia, vol. II.

. (1913), Annuario do Ensino do Estado de São Paulo - 1913. São Paulo: Typ. Siqueira.

. (1917a), Annuario do Ensino do Estado de São Paulo - 1916. São Paulo: Typ. do "Diario Official".

(1917b), Annuario do Ensino do Estado de São Paulo - 1917. São Paulo: Typ. Augusto Siqueira \& C., vol. I. 
(1917c), Annuario do Ensino do Estado de São Paulo - 1917. São Paulo: Typ. Augusto Siqueira \& C., vol. II.

(1918), Annuario do Ensino do Estado de São Paulo - 1918. São Paulo: Typ. Augusto Siqueira \& C.

. (1920-1921), Annuario do Ensino do Estado de São Paulo - 1920-1921. São Paulo: Typ. Augusto Siqueira \& C.

. (1940), São Paulo, 1889-1939. São Paulo: DEE.

. Vários anos. Orçamentos e Balanços de Receitas e Despesas Provinciais, Fundo Assembleia Legislativa Provincial - Império. Acervo Histórico da Assembleia Legislativa de São Paulo. 


\section{RESUMO \\ Contando o Atraso Educacional: Despesas e Matrículas na Educação Primária de São Paulo, 1880-1920}

Este artigo analisa o desempenho educacional de São Paulo em um período-chave das transformações econômicas e sociais ocorridas no Brasil que acompanharam o boom das exportações de café no final do século XIX e início do século XX. Ainda abaixo da média nacional em 1870, o Estado de São Paulo alcançou nas décadas seguintes uma das maiores taxas de matrícula e tornou-se um dos líderes da educação primária no Brasil já em 1920. O artigo apresenta novas séries de despesas e matrículas que, combinadas com indicadores que medem o esforço fiscal realizado em diferentes períodos, trazem à luz fatos pouco reconhecidos sobre as escolas primárias de São Paulo entre 1880 e 1920. Primeiro, o acesso ao ensino primário - em São Paulo e no Brasil - continuou extremamente restrito e desigual, pouco se diferenciando da situação de atraso em relação aos indicadores internacionais em meados do século XIX. Segundo, o excepcional crescimento das riquezas privadas e das receitas fiscais em São Paulo não foi acompanhado pelos gastos com educação primária. A discrepância entre o ritmo de crescimento das receitas públicas e das despesas com instrução primária levou a um resultado surpreendente: nas primeiras décadas da República em São Paulo, o esforço fiscal destinado à educação primária caiu para a metade do realizado durante os últimos 10 anos do Império.

Palavras-chave: educação primária; desigualdade; São Paulo

\section{ABSTRACT \\ Educational Delay in Numbers: Expenses and Enrollment in Primary Education in São Paulo, 1880-1920}

This article analyzes the educational performance of São Paulo in a key period of the economic and social transformations that occurred in Brazil following the boom in coffee exports in the late nineteenth and early twentieth centuries. Still below the national average in 1870, the state of São Paulo reached in the following decades one of the highest enrollment rates and became one of the leaders of primary education in Brazil as early as 1920. The paper presents new series of expenses and enrollments which, combined with indicators that measure the fiscal effort carried out in different periods, bring to light little-known facts about the primary schools of São Paulo between 1880 and 1920. First of all, access to primary education - in São Paulo and Brazil - remained extremely restricted and unequal, little differing from the situation of backwardness in relation to international indicators in the mid-nineteenth century. Secondly, the exceptional 
growth of private wealth and tax revenues in São Paulo wasn't accompanied by expenditures on primary education. The discrepancy between the growth rates of public revenues and expenditures on primary education led to a surprising result: in the first decades of the Republic in São Paulo, the fiscal effort for primary education fell to half of what was current during the last 10 years of the Empire.

Keywords: primary education; inequality; São Paulo

\section{RÉSUMÉ}

Compter le Retard Scolaire: Dépenses et Inscription dans l'Enseignement Primaire à São Paulo (1880-1920)

Cet article analyse les résultats scolaires de São Paulo à une période très important pour les transformations économiques et sociales qui ont accompagné l'essor des exportations de café à la fin du XIX et au début du XX siècle, au Brésil. Au dessous de la moyenne nationale courant les années 1870, pendant les décennies suivantes l'État de São Paulo a atteignu l'un des taux de scolarisation les plus élevés du pays et a devenu dès 1920 l'un des leaders de l'Enseignement Primaire. Icy, on présente une nouvelle série de dépenses et d'inscriptions qui, combinés avec des indicateurs qui mesurent l'effort budgétaire réalisé à différentes périodes, mettent en lumière des faits méconnus sur les écoles primaires à São Paulo entre 1880 et 1920. Premièrement, l'accès à l'Enseignement Primaire - à São Paulo et au Brésil - restait extrêmement limite et inégale, sans différence à la situation de retard par rapport aux indicateurs internationaux du milieu du XIXe siècle. Deuxièmement, la croissance exceptionnelle de la richesse privée et des recettes fiscales à São Paulo ne s'est pas accompagnée de dépenses consacrées à l'Enseignement Primaire. L'écart entre le taux de croissance des recettes publiques et les dépenses consacrées à l'Enseignement Primaire a conduit à un résultat surprenant: au cours des premières décennies de la République à São Paulo, l'effort budgétaire consacré à l'Enseignement Primaire a été réduit de moitié par rapport à ce qu'il avait été durant les dix dernières années de l'époque de l'Empire.

Mots-clés: enseignement primaire; inégalité; São Paulo 


\section{RESUMEN}

Contando el Atraso Educacional: Gastos y Matrículas en la Educación Primaria de São Paulo, 1880-1920

Este artículo analiza el desempeño educacional de São Paulo en un período clave de transformaciones económicas y sociales ocurridas en Brasil que acompañaron el boom de las exportaciones de café al final del siglo XIX e inicio del siglo XX. Aún por debajo de la media nacional en 1870, el Estado de São Paulo alcanzó en las décadas siguientes una de las mayores tasas de matrícula y se convirtió en uno de los líderes de la educación primaria en Brasil en 1920. El artículo presenta nuevas series de gastos y matrículas que, combinadas con indicadores que miden el esfuerzo fiscal realizado en diferentes períodos, traen a la luz hechos poco reconocidos sobre las escuelas primarias de São Paulo entre 1880 y 1920. Primero, el acceso a la enseñanza primaria - en São Paulo y en Brasil - continuó extremamente limitado y desigual, diferenciándose poco de la situación de atraso en relación a los indicadores internacionales de mediados del siglo XIX. Segundo, el excepcional crecimiento de las riquezas privadas y de los ingresos fiscales en São Paulo no estuvo acompañado por los gastos de educación primaria. La discrepancia entre el ritmo de crecimiento de los ingresos públicos y de los gastos de instrucción primaria llevó a un resultado sorprendente: en las primeras décadas de la República en São Paulo, el esfuerzo fiscal destinado a la educación primaria disminuyó a la mitad del realizado durante los últimos 10 años del Imperio.

Palabras clave: educación primaria; desigualdad; São Paulo 